\title{
Ayurveda and the Autumn/Winter Seasons
}

\section{Cristina $\mathrm{L}^{*}$}

Iyengar Yoga Association, Netherlands

Conceptual Paper

Volume 1 Issue 1

Received Date: February 07, 2017

*Corresponding author: Mrs Cristina Libanori, Iyengar Yoga Association,

Published Date: February 14, 2017

Netherlands, E-mail: cristina@the-wheel-of-yoga.com

\section{Introduction}

Just as our bodies are made up of trillions of independent cells, we are all little cells in the universal organism. Just like our cells, each of us humans has an individual existence, but none of could exist isolated, independently.

All which is outside is inside according to Ayurveda and this makes the whole concept very approachable and comprehensible. Everything existing outside finds its counterpart in a living being's own personal existence or interval universe. Every cosmic force is represented within our personal embodiment. But how can we begin to apply Ayurvedic philosophy to to everyday's life? Including the daily Yoga practice, So to synchronize with the universe outside and bring more balance into our life? One of the most communal questions normally receive as an Iyengar Yoga teacher \& Ayurveda therapist is generally..

Which Asanas are the most suitable for different body types, constitutions? Let's start with by explaining that Ayurveda names different constitutions as Doshas. What is a Dosha? It is our mind/body principle or individual constitution which is also exists and is manifested in the universe.

A Dosha is based on the presence of Elements and in their quantity in our embodiment. It is important to remember that elements in the body are just like elements outside in nature and in the world around us. Our daily maintenance work consists in keeping balance amongst elements according to the blueprint of our individual Prakrthi (nature).
The 5 Elements are the pancha Maha Buthas- namely the 5 great elements:

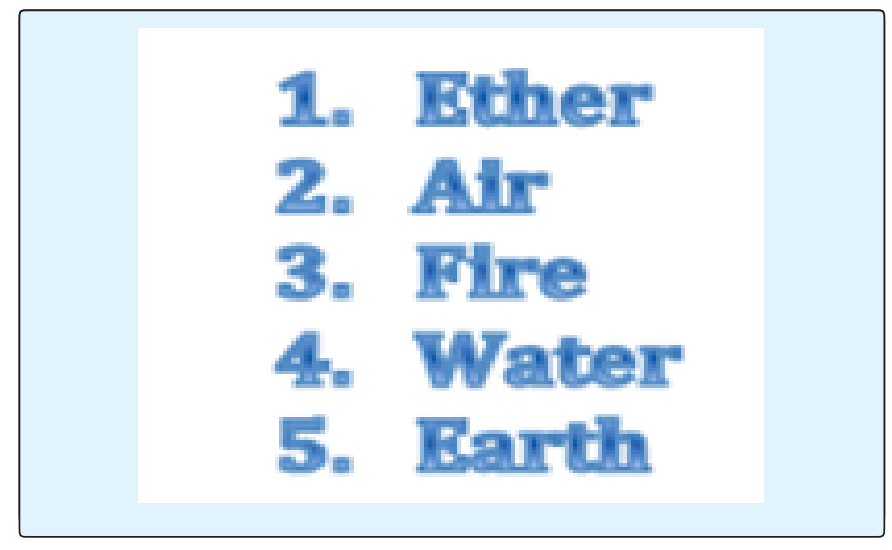

Depending on the combination of the 5 Elements and their quantity present in the individual, a Dosha is defined

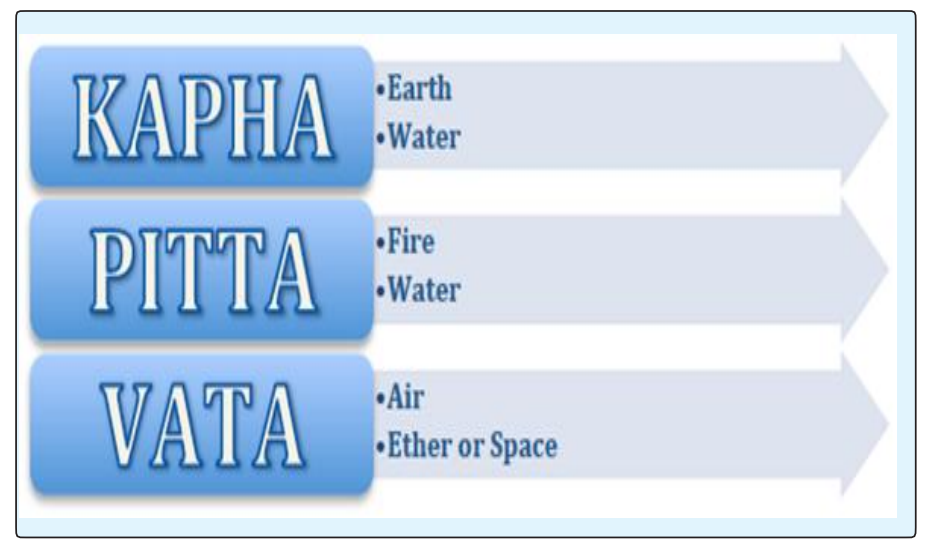

Each Dosha is characterized by specific Qualities which are inherited by the elements composing the Dosha 


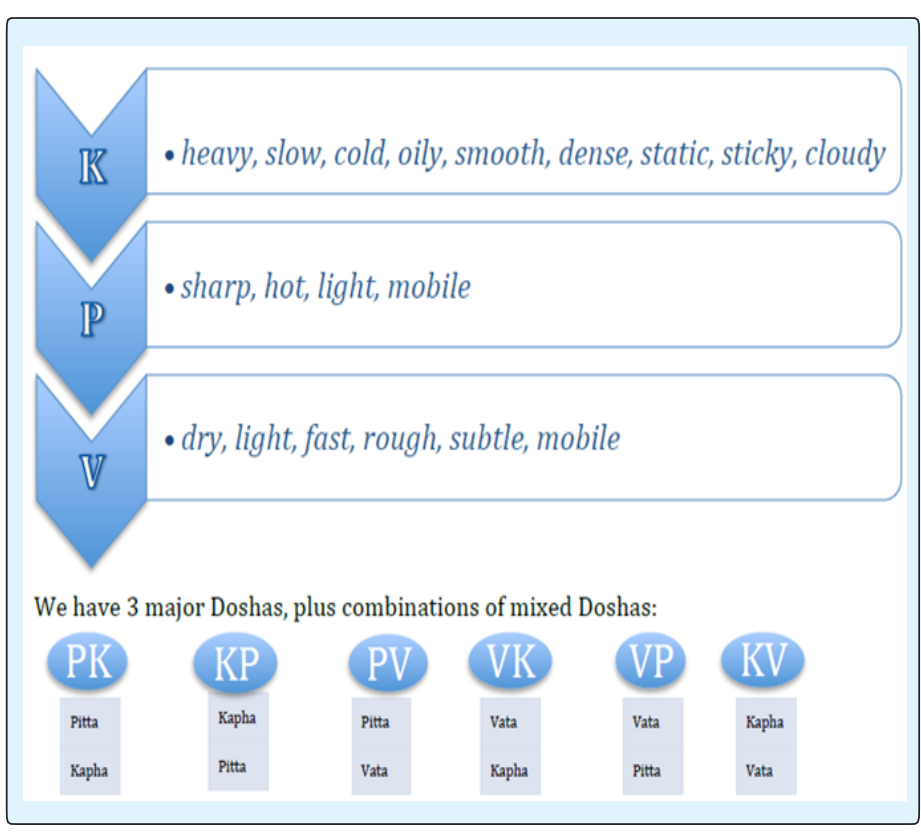

Most of us possess mixed Doshas. Unique Dosha constitutions are quite rare.Oncethe individual Dosha is defined, we than look into the current season and its characteristics so to finally tune the Yoga Practice, according to the season of the year.

\section{A Yoga Sequence for Autumn}

Even without knowing the individual Dosha, one can always apply an approach to balancing Pitta \& Vatta Dosha, by taming Fire and Air elements in the Yoga sequence and/or by increasing Kapha intensifying the Earth element of the practice. The earth element is required for stabilizing, grounding to find a better balance in a season which is all about transformation.

In Ayurveda the autumn season corresponds to two predominant Doshas

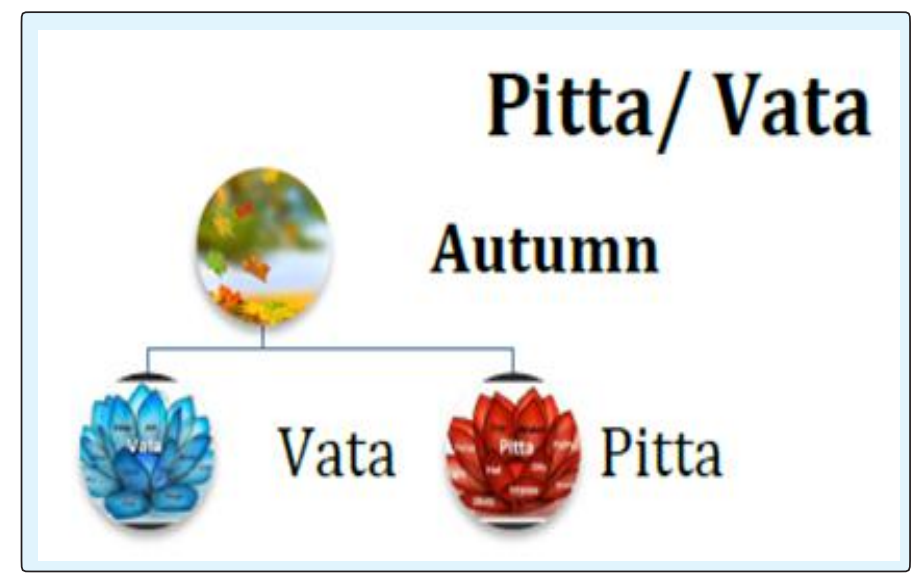

Pitta is made of Fire and Autumn is considered Pitta as long as hot weather prevails. Autumn is Vata when in turns into winter as the weather becomes cold. Late fall and winter are known as Vata season because they are marked by many of the qualities that characterize the Vata season, Vata is made up of air and space and its qualities are cold, dry, light, clear and moving.

As long as these qualities are in balance, a person with a Vata Dosha will be healthy, exuberant, creative, like a joyful playful wind in Nature.

During this period of the year though, Vata, which is predominant in Autumn/Winter in Nature, will also accumulate in the body and mind and may easily bring a Vata constitution person to imbalance. Other constitutions will be less affected by the Autumn qualities of Pitta. All body types are vulnerable to the derangement of Vata in autumn and winter but the predominantly Vata types need to be more attentive about staying in balance.

The imbalances of high Vata in Autumn manifest at physical and/or emotional level with symptoms as insomnia, arthritis, dry skin, mucus, constipation, high blood pressure, depression and anxiety.

An example of a suitable Yoga practice in Autumn to prevent or cure the above symptoms could be standing poses as in Virabhadrasana I and II, twists as in Ardha Matsyendrasana, pasasana, Parivritta, Trikonanasa side stretches as in Parivritta Janu Sirsasana, backbends as in Dhanurasana, Ustrasana. Finally enjoying a long Savasana to stabilize the moving energy of Vata in the body as it is the energy of wind in the Autumn days. 